\title{
Synthetic Oligodeoxynucleotide Probes for the Rapid Detection of Bacteria Associated with Human Periodontitis
}

\author{
By PAUL J. CHUBA,${ }^{1}$ KLAUS PELZ, ${ }^{1}$ GISBERT KREKELER, ${ }^{2}$ \\ TERESA S. DE ISELE ${ }^{1}$ AND ULF GÖBEL ${ }^{1 *}$ \\ ${ }^{1}$ Institut für Medizinische Mikrobiologie und Hygiene der Universität Freiburg, \\ Hermann Herder Strasse 11, D-7800 Freiburg, FRG \\ ${ }^{2}$ Zentrum für ZMK, Sektion Parodontalchirurgie, Hugstetter Strasse 55, D-7800 Freiburg, FRG
}

(Received 1 February 1988; revised 21 March 1988)

\begin{abstract}
Analysis of the subgingival microflora has recently implicated Actinobacillus (Haemophilus) actinomycetemcomitans and several black Bacteroides species in the aetiology of juvenile, adult and rapidly progressing periodontitis. Rapid bacteriological diagnosis has been hampered by the slow growth and fastidious nature of these bacteria. To construct diagnostic probes, dideoxy sequencing of the 16S rRNA molecules from A. $(H$.) actinomycetemcomitans, Haemophilus aphrophilus, Bacteroides gingivalis, Bacteroides intermedius subgroup II, Bacteroides asaccharolyticus and several closely related species was performed. Next, oligodeoxynucleotides, complementary to defined regions of the 16S rRNA exhibiting considerable evolutionary divergence, were synthesized for use as molecular probes. In a dot-blot hybridization assay, all strains from each of the species for which probes were constructed were correctly identified, with a detection limit of less than $5 \times 10^{3}$ organisms. No cross-hybridization to closely related species (except for $H$. aphrophilus and Haemophilus paraphrophilus) or contaminating bacteria was observed. Using a modified DNA/RNA hybridization technique, the detection could be performed in less than $12 \mathrm{~h}$, as compared to $2-3$ weeks using conventional bacteriological procedures.
\end{abstract}

\section{INTRODUCTION}

Periodontal infections are a major cause of alveolar bone destruction and tooth loss worldwide. The aetiology and pathogenesis of periodontal infections in both juveniles and adults have recently come under intensive investigation (Haapasalo et al., 1986; Moore et al., 1984, 1987; Moore, 1987). Although up to 325 different bacterial species have been isolated from periodontal pockets (Moore, 1987), relatively few Gram-negative anaerobes and facultative anaerobes appear to be implicated in the process of subgingival colonization and pocket formation (Newman \& Socransky, 1977; Slots, 1979; Slots et al., 1985; Gmür et al., 1986); however, more work needs to be done to establish statistical comparisons and to reconcile results from various laboratories (Moore et al., 1987). Most closely associated with juvenile-onset periodontitis have been Actinobacillus (Haemophilus) actinomycetemcomitans (Cristersson et al., 1985; Zambon, 1985), and Capnocytophaga species (Slots \& Genco, 1984). Rapidly progressing periodontitis has been characterized by the presence of one or more of the organisms Bacteroides gingivalis, A. ( H.) actinomycetemcomitans, Fusobacterium nucleatum and oral spirochaetes. Blackpigmented Bacteroides species, mainly Bacteroides intermedius, seem to be associated with the adult forms of periodontal disease (Duerden et al., 1987). Eikenella corrodens, Haemophilus aphrophilus and Actinomyces species, among numerous others, have also been isolated from mixed infections in periodontitis (Moore et al., 1985).

Although timely microbiological detection would be useful for the assessment of prognosis, for epidemiological studies, and for possible antimicrobial therapy in periodontal disease, rapid diagnosis has been hampered by the time required for conventional identification of the bacteria 
involved. Several methods for the rapid detection of selected periodontal pathogens have been reported. These include immunofluorescence using monoclonal or polyclonal antibodies (Bonta et al., 1985; Miyoshi et al., 1986; Cristersson et al., 1987a b), and DNA/DNA hybridization using either random cloned DNA fragments (Salyers et al., 1983; Kuritza et al., 1986) or whole genomic DNA isolated from the organisms of interest (French et al., 1986; Strzempko et al., 1987; Roberts et al., 1987) as probes. DNA/RNA hybridization procedures for detection of pathogenic bacteria have also been developed (Falkow, 1985; Eisenstein \& Engelberg, 1986; Göbel et al., 1987a, b; Haun \& Göbel, 1987; Viscidi \& Yolken, 1987), and we describe here the application of a DNA/RNA dot-hybridization procedure for the species-specific detection of $A$. (H.) actinomycetemcomitans, $H$. aphrophilus, B. gingivalis, B. intermedius subgroup II and $B$. asaccharolyticus.

\section{METHODS}

Bacterial strains and media. Bacterial strains were obtained from the National Collection of Type Cultures Collection (NCTC), London, UK, from the Deutsche Stammsammlung für Mikroorganismen (DSM), Braunschweig,FRG, from our own collection and from the collection of Professor W. Mannheim (Marburg, FRG). The strain designations and original sources are given in Table 1. Although the suggestion has been made to move the species Actinobacillus actinomycetemcomitans into the genus Haemophilus (Potts et al., 1985), the International Committee on systematic bacteriology has not yet favoured this proposal (Frederiksen, 1987), and we therefore refer to it here as Actinobacillus (Haemophilus) actinomycetemcomitans. Bacteroides species were identified using established bacteriological techniques. SDS-PAGE was used to differentiate $B$. intermedius I and $B$. intermedius II. YCB-blood agar $[10 \%(v / v)$ defibrinated sheep blood, $1 \%(\mathrm{w} / \mathrm{v})$ peptone, $0 \cdot 5 \%(\mathrm{w} / \mathrm{v}) \mathrm{NaCl}, 0.2 \%$ $(\mathrm{w} / \mathrm{v})$ meat extract, $0.5 \%(\mathrm{w} / \mathrm{v})$ yeast extract, $0.03 \%(\mathrm{w} / \mathrm{v})$ L-cysteine chloride monohydrate, $2 \%(\mathrm{w} / \mathrm{v})$ glucose, $1.8 \%(\mathrm{w} / \mathrm{v})$ Difco agar] supplemented with $0.001 \%(\mathrm{w} / \mathrm{v})$ haemin and $0.0001 \%(\mathrm{w} / \mathrm{v})$ vitamin $\mathrm{K}$ was used for anaerobic cultivation, Columbia green blood agar (Oxoid) was used for aerobic cultures, and Malachite green blood agar $\left[5 \%(\mathrm{w} / \mathrm{v})\right.$ sheep blood, $3.8 \%(\mathrm{w} / \mathrm{v})$ trypticase soya agar, $128 \mathrm{mg}$ bacitracin $1^{-1}$, and $8 \mathrm{mg}$ malachite green $\mathrm{ml}^{-1}$ ] was used as a selective medium for $\boldsymbol{A}$. $(H$.) actinomycetemcomitans and $H$. aphrophilus (Lennette et al., 1985). Gas chromatography was routinely performed on anaerobic isolates.

Isolation of $r R N A$. Bulk cellular RNA was isolated as follows. Bacterial cultures $(500 \mathrm{ml})$ were grown to midexponential phase in Brain Heart Infusion medium at $37{ }^{\circ} \mathrm{C}$ without shaking. Actinobacillus species were incubated in $5 \%(\mathrm{v} / \mathrm{v})$ carbon dioxide, and Bacteroides species were grown using the Gas-Pak system (Merck). Cells were harvested by centrifuging at 6500 r.p.m. for $10 \mathrm{~min}$ at $4{ }^{\circ} \mathrm{C}$ in a Sorvall GSA rotor. The pellets were resuspended in $100 \mathrm{ml}$ phosphate-buffered saline, and recentrifuged at $6500 \mathrm{r} . \mathrm{p} . \mathrm{m}$. for $10 \mathrm{~min}$. The washed cells were resuspended in $20 \mathrm{ml} 4 \mathrm{M}-\mathrm{LiCl}, 8 \mathrm{M}$-urea and incubated for $16 \mathrm{~h}$ at $0{ }^{\circ} \mathrm{C}$ (Auffray \& Rougeon, 1980). After centrifugation at 10000 r.p.m. for $20 \mathrm{~min}$ in a Sorvall SS34 rotor, $10 \mathrm{ml} \mathrm{TE}$ buffer (TE is $0.01 \mathrm{M}$-Tris/ $\mathrm{HCl}, 0.001 \mathrm{M}$ EDTA, pH 8.0) was added to the wet pellet. Next, two extractions with an equal volume of TE-saturated phenol, followed by a single extraction with $24: 1$ (v/v) chloroform/isoamyl alcohol, were performed. Finally, two volumes of ice-cold ethanol were added, and the RNA preparations stored at $-20^{\circ} \mathrm{C}$

Reverse transcriptase sequencing of $16 \mathrm{~S}$ rRNAs. $16 \mathrm{~S}$ rRNA sequence data were obtained using the dideoxy chain termination method (Sanger et al., 1977). Bulk cellular RNA served as template, and synthetic deoxyoligonucleotides complementary to conserved regions of the $16 \mathrm{~S}$ rR NAs were used as 'universal' primers (see below), together with avian myeloblastoma virus reverse transcriptase (Pharmacia), essentially as described by Lane et al. (1985) and Pace et al. (1986). The final concentrations of deoxy and dideoxy nucleotides in the reaction mixes were as follows: dNTPs, $100 \mu \mathrm{M}$; ddCTP, $12 \mu \mathrm{M}$; ddTTP, $12 \mu \mathrm{M}$; ddATP, $5 \mu \mathrm{M}$; ddGTP, $8 \mu \mathrm{M}$.

Synthesis of deoxyoligonucleotides. Deoxyoligonucleotides, for use as sequencing primers or hybridization probes (15-32 bases in length), were synthesized on a solid support with an Applied Biosystems 380A DNA synthesizer using diisopropylphosphoramidite chemistry. Oligonucleotides were purified by electrophoresis on native $20 \%$

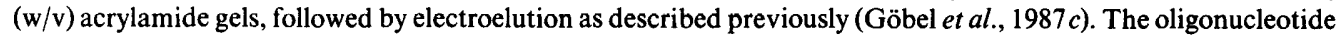
primers (with which the sequence data discussed here were obtained) had the sequences 5'CCCGTCAATTCCTTTGAGTTT 3' and 5'TACCAGGGTATCTAATCCTGTT 3', and were complementary to the 'U4' and 'U5' conserved regions of the prokaryotic 16S rRNA molecule, respectively (Gray et al., 1984). The sequences of oligonucleotides used for probe construction are given in Fig. 1.

Hybridizations. For 'slot-blot' hybridization of bacterial cultures, whole cells were resuspended in $1 \mathrm{ml} 0 \cdot 15 \mathrm{M}$ $\mathrm{NaCl}$ to a final concentration of approximately $5 \times 10^{7}$ cells $\mathrm{ml}^{-1}$, and samples of $50 \mu \mathrm{l}, 25 \mu \mathrm{l}$ and $10 \mu \mathrm{l}$ were blotted directly (without further handling) onto nylon membranes (Pall) using the Minifold I and Minifold II filtration manifolds (Schleicher and Schuell). Filters were subsequently baked for $2 \mathrm{~h}$ at $80^{\circ} \mathrm{C}$. Oligonucleotide probes were end-labelled with $\left[\gamma^{-32}\right.$ P]ATP $\left(5000 \mathrm{Ci} \mathrm{mmol}{ }^{-1}, 185 \mathrm{TBq} \mathrm{mmol}^{-1}\right.$; Amersham) using T4 polynucleotide kinase (BRL) according to the recommendations of the supplier, and purified on $20 \%$ polyacrylamide gels followed by electroelution. Filters were prehybridized for $30 \mathrm{~min}$ at $65^{\circ} \mathrm{C}$ in a hybridization 
Probe BG-32: comparison of B. gingivalis and B. fragilis V8 variable region

3 'ATCCTCAAACGCTATATGGCAGTTCGAAGGTG 5' DNA BG-32 5 'AUGAUUACUAGGAGUUUGCGAUAUACCGUCAAGCUUCCACAGCGAAAgCGUUA 3 'RNA B. $\mathrm{g}$. 5 'AUGAAUACUCGCUGUUUGCGAUAUACAGUA-AGCGGCCA-AGCGAAAGCAUUA 3 'RNA B. $\star \star \star \star$

Probe BI-31: comparison of B. intermedius and B. fragilis V7 variable region

3 'GGACTCATGTGCGTCGCGTCCGCCTTAAGTA 5' DNA BI-31 5 'CUGUCAGACCUGAGUACACGCAGCGCAGGCGGAAUUCAUGGUGUAGCGGUGA 3 'RNA B. i. 5 ' CUGUCAGUCUUGAGUACAGUAGAGGUGGGCGGAAUUCGUGGUGUAGCGGUGA 3 'RNA B.f. $\star \star \quad * * \star \star \star * \star * *$

Probe BA-30: comparison of B. asaccharolyticus and B. fragilis V7 variable region

3'GAGTACGATCTCACATGACCTCCATGCACC 5'

DNA BA-30

5 'AAACUCUCUCAUGCUAGAGUGUACUGGAGGUACGUGGNNCGUGUGGUG 3 'RNA B.a. 5 'UGAUACUGUCAGUCUUGAGUACAGUAGAGGUGGGCGGAAUUCGUGGUG 3 'RNA B. $f$ $* * * * * * * * * * * * * * * *$

Probes AAC-25 and HA-25: comparison of $\boldsymbol{A}$. (H.) actinomycetemcomitans, 'A. hominis' and $H$. aphrophilus

V8 variable region

3' CCCCTAACCCCAAATCGGGACCACG 5 ' 3'AACACGAAACTCGAACCACGGACATCGA $5{ }^{\prime}$ 5 'GUCGAUUUGGGGAUUGGGGUUUAGCCCUGGUGCCCNAAGCUAACGUGAU 3 'RNA A. aC. 5 'GUGCAUUUGGGGAUUGUGCUUUGAGCUUGGUGCCUGUAGCUAACGUGAU 3 'RNA $\mathrm{H} . \mathrm{a}$. 5 'GUCGAUUUGgGgAUUgGaCUGUGAgUCUGgUGCCCUAAGCUAACGUGAU 3 'RNA A. $\mathrm{h}$.

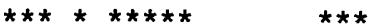

Fig. 1. Comparison of representative partial 16S rRNA sequences corresponding to variable regions V7 and V8. The Bacteroides fragilis (Weisburg et al., 1985) sequence was compared with the Bacteroides sequences determined here to select the complementary oligonucleotide probes BG-32, BI-31, and BA30. Actinobacillus hominis, $A$. $(H$.) actinomycetemcomitans, and $H$. aphrophilus sequences were compared to select the probes AAC-25 and HA-28. Positions of nonidentity are indicated with an asterisk; $\mathrm{N}=$ ambiguous. B.g., B. gingivalis; B.f., B. fragilis; B.i., B. intermedius II; B.a., B. asaccharolyticus; A.ac., A. (H.) actinomycetemcomitans; A.h., 'A. hominis'; H.a., H. aphrophilus.

buffer consisting of $5 \times \mathrm{SSC}(1 \times \mathrm{SSC}$ is $0.15 \mathrm{M}-\mathrm{NaCl}, 0.015 \mathrm{M}$-sodium citrate), $5 \times$ Denhardt's solution $(1 \times$ Denhardt's solution is $0.02 \%$ bovine serum albumin, $0.02 \%$ polyvinylpyrrolidone and $0.02 \%$ Ficoll), $0.2 \%$ SDS, and $250 \mathrm{mg}$ yeast tRNA ml${ }^{-1}$. Subsequently, 1-2 $\times 10^{6}$ c.p.m. of end-labelled oligonucleotide in hybridization buffer was applied to each filter, and hybridization was allowed to proceed for $1-2 \mathrm{~h}$ at $65^{\circ} \mathrm{C}$. After hybridization, each filter was washed once for $2 \mathrm{~min}$ at $65^{\circ} \mathrm{C}$ in $5 \times \mathrm{SSC}, 0.2 \% \mathrm{SDS}$, air dried, and autoradiography was performed using Kodak X-OMAT film with intensifier screens $(2-12 \mathrm{~h})$ at $-70^{\circ} \mathrm{C}$.

In order to determine the sensitivity of the probes in detecting bacteria on filters, serial dilutions were tested for colony-forming units (c.f.u.), and in parallel, samples were applied to filters and hybridized as described above. To test the influence of the presence of contaminating bacteria on the species-specific hybridization, exponentialphase liquid cultures $\left(5 \times 10^{7}\right.$ cells $\left.\mathrm{ml}^{-1}\right)$ of Bacteroides intermedius II and Bacteroides gingivalis were diluted serially, mixed in various ratios as shown in Fig. 2, applied to filters, and hybridized using species-specific probes to one or the other organism.

\section{RESULTS}

\section{$16 S$ rRNA sequencing}

Bulk cellular rRNA isolated from $A$. ( $H$.) actinomycetemcomitans NCTC 9710, $H$. aphrophilus NCTC 5906, 'A. hominis' NCTC 11529, B. gingivalis DSM 20709, B. intermedius II NCTC 9336 and $B$. asaccharolyticus NCTC 9337 were used as templates in chain-termination sequencing reactions using oligonucleotide primers and reverse transcriptase. Partial $16 \mathrm{~S}$ rRNA sequences obtained were compared with those of closely related organisms, including $B$. fragilis for the black Bacteroides species (Weisburg et al., 1985), for the selection of species-specific probes. The relevant rRNA sequence alignments are shown in Fig. 1. For the purposes of this analysis, the 


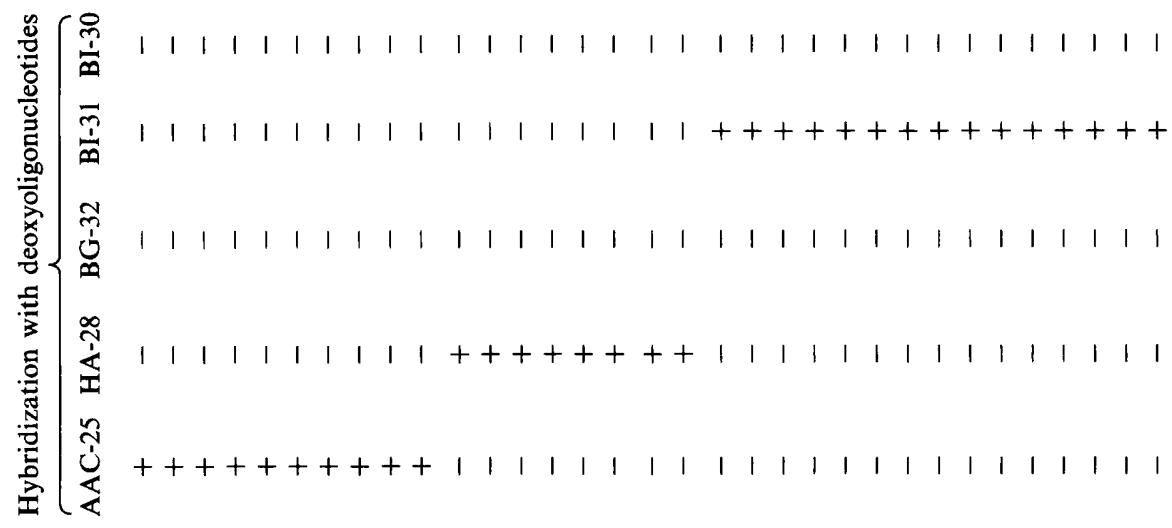

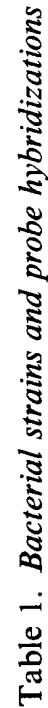

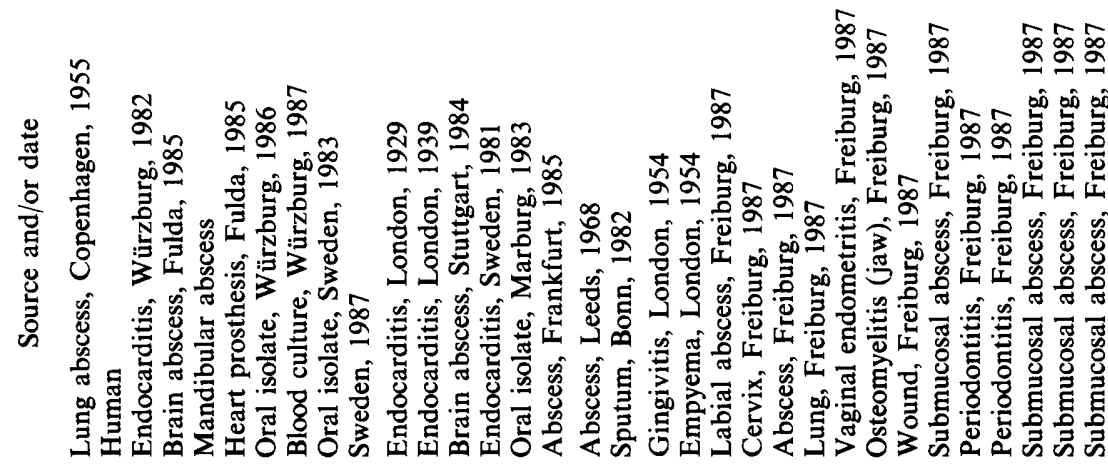

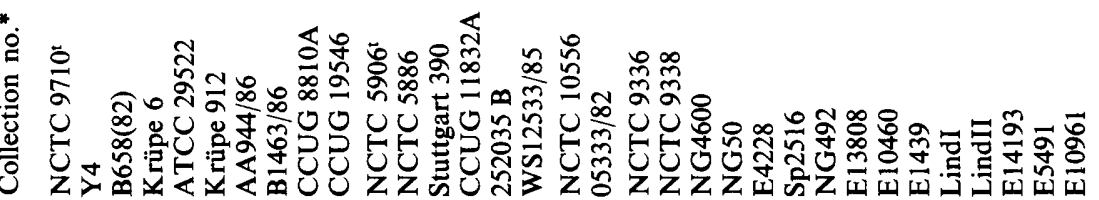
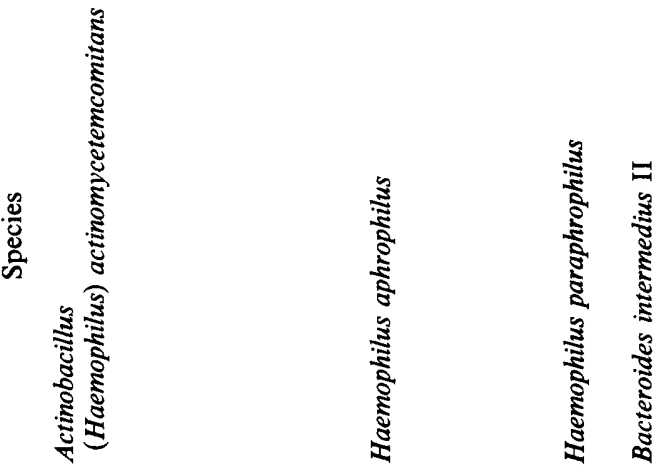


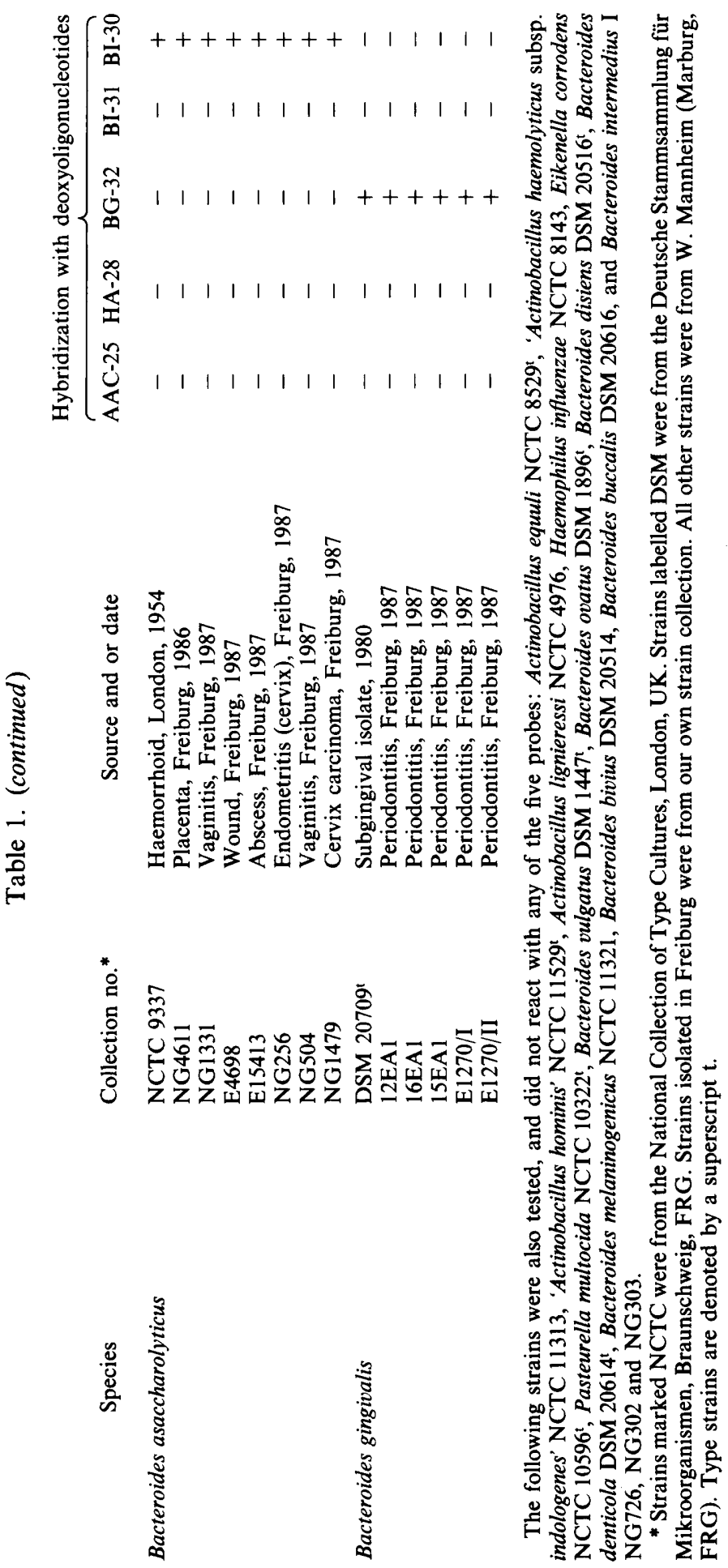


B. gingivalis

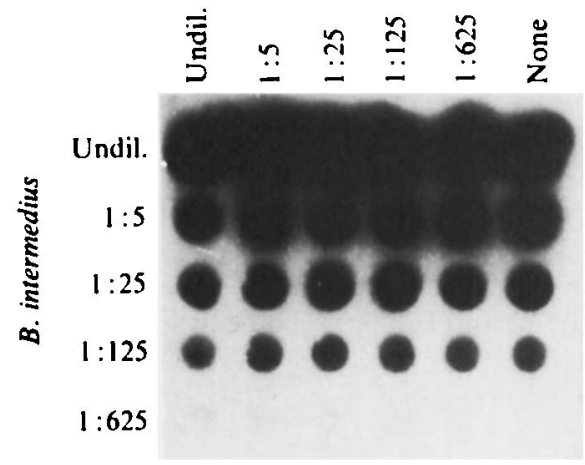

Probe BI-3I
B. intermedius

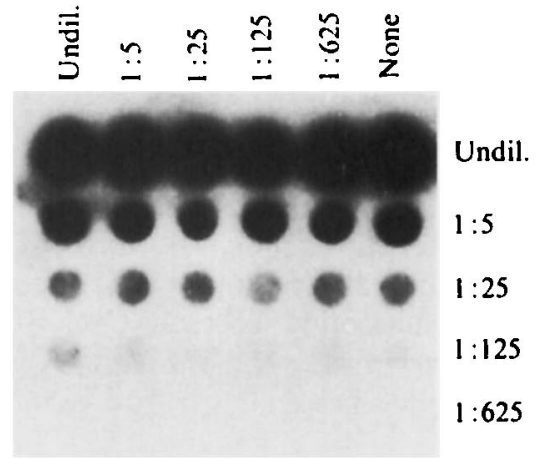

Probe BG-32

Fig. 2. Effect of contaminating bacteria on the oligonucleotide hybridization assay (probes BG-32 and BI-31). Hybridizations of fivefold dilutions of suspensions of B. gingivalis and B. intermedius II mixed and applied to filters in various ratios are shown.

variable region $\mathrm{V} 7$ and $\mathrm{V} 8$ sequences ( $E$. coli $16 \mathrm{~S}$ rRNA nomenclature according to Gray et al., 1984) were considered. The sequences selected for the construction of oligonucleotide probes AAC-25 (for $A$. ( $H$.) actinomycetemcomitans), HA-28 (for $H$. aphrophilus), BG-32 (for $B$. gingivalis), BI-31 (for B. intermedius), and BA-30 (for B. asaccharolyticus) are also given in Fig. 1.

\section{Probe specificity}

The results of slot-blot hybridization experiments using the oligonucleotide probes described above are shown in Table 1. A number of species belonging to the genera Bacteroides, Haemophilus and Actinobacillus, as well as several more distantly related bacteria, were tested. Oligonucleotide BG-32 hybridized only to $B$. gingivalis (Table 1). The B. gingivalis type strain was identified as were five clinical isolates. Oligonucleotide AAC-25 identified the $A$. $(H$.) actinomycetemcomitans type strain as well as nine strains from the collection of W. Mannheim (Marburg, FRG). Oligonucleotide HA-28 hybridized with both $H$. aphrophilus (six strains) and $H$. paraphrophilus (two strains), indicating a close genotypic similarity between the two species. Phenotypically, these species differ only in the requirement for $\mathrm{V}$ factor. Oligonucleotide BI-31 hybridized specifically with $B$. intermedius subgroup II (15 strains), but did not recognize three strains of $B$. intermedius subgroup I. These subgroups may represent different species (Johnson \& Harich, 1966). Oligonucleotide BG-30 hybridized with $B$. asaccharolyticus NCTC 9337, and with seven clinical isolates. None of the probes reacted with any of the other species listed in Table 1. All of the clinical strains isolated in Freiburg (Table 1) which tested positive for one of the probes were also verified by phenotypic testing.

\section{Probe sensitivity}

To determine the number of bacteria which could be detected using these probes, viable count determinations were performed on exponential-phase cultures, dilutions of which were then applied to hybridization filters. Each of the five probes detected between $1 \times 10^{3}$ and $5 \times 10^{3}$ c.f.u. (data not shown). This is in good agreement with the detection limit of about $1 \times 10^{3}$ c.f.u. for probes specific for the genus Proteus previously determined in this laboratory (Haun \& Göbel, 1987).

Although the probes showed no cross-reactivity when bacteria from pure cultures were tested, it was possible that the presence of closely related bacteria in mixed or contaminated cultures could affect the specificity or sensitivity of the hybridization. Fig. 2 shows that neither the sensitivity nor the specificity of hybridization of $B$. gingivalis with oligonucleotide BG-32 at various concentrations was affected by the presence of $B$. intermedius II at various concentrations, nor was hybridization of $B$. intermedius II with oligonucleotide BI-31 affected by the presence of $B$. gingivalis. 


\section{DISCUSSION}

Definitive microbiological analysis of multiple samples from periodontitis patients has hitherto been very time consuming and expensive. Although tests based on immunofluorescence are in development, and DNA/DNA hybridization tests have been described (see Introduction), identification of the obligate and facultative anaerobes associated with periodontitis is currently based on biochemical tests. This usually requires a period of two weeks between obtaining pure cultures and reporting results, primarily due to the fastidious nature of the bacteria involved and the complexity of the subgingival flora. Using the hybridization probes described here, the detection of bacteria in multiple samples could be performed rapidly $(12 \mathrm{~h})$, using a simple assay. The oligonucleotide probes AAC-25, BG-32, BI-31 and BA-30 were species-specific for $A$. $(H$.) actinomycetemcomitans, $B$. gingivalis, $B$. intermedius II and $B$. asaccharolyticus respectively, and oligonucleotide HA-28 hybridized with two closely related species $H$. aphrophilus and $H$. paraphrophilus (Table 1).

The approach described here combines important attributes of rapid molecular sequencing and hybridization methods for diagnostic applications. (1) The unique architecture of the $16 \mathrm{~S}$ rRNA allows direct sequencing. Molecular cloning is therefore unnecessary, as is the screening of large numbers of DNA fragments for specificity in hybridization reactions. (2) Automated synthesis is now widely available to construct defined oligonucleotide probes, in contrast to whole genomic DNA, where the quality may vary from one preparation to another. (3) The target molecule for the probes is the $16 \mathrm{~S}$ rR NA molecule, present in very high copy numbers $\left(10^{4}\right.$ molecules per cell, compared with only one copy for most prokaryotic genes), allowing for favourable hybridization kinetics and high sensitivity (detection limit about $5 \times 10^{3}$ bacteria). (4) Unlike whole genomic DNA probes directed against the same species, which tend to crossreact with closely related species (Strzempko et al., 1987), four out of five of the oligonucleotides described here showed no cross-reactivity, and one probe (HA-28) cross-reacted only with a single very close relative (Table 1). (5) Short hybridization times (1-2 h for oligonucleotides versus 12-24 h for large DNA fragments of whole genomic DNA probes), exact prediction of hybridization conditions (Conner et al., 1983), and easy handling of large sample numbers, make oligonucleotide hybridization assays attractive for both rapid diagnosis and extended epidemiological studies of periodontal infections.

This study was funded by Bundesministerium für Forschung und Technologie grant PTB038770. We thank Renate Bock, Gabriele Graf, Siegrid Kiedrowski and Dr Thomas Adam for technical support. We are indebted to Dr Wolfgang Bredt for helpful discussions. The generosity of Dr W. Mannheim is gratefully acknowledged.

\section{REFERENCES}

Auffray, C. \& Rougeon, F. (1980). Purification of mouse immunological heavy-chain messenger RNAs from total myeloma tumor RNA. European Journal of Biochemistry 107, 303-314.

Bonta, Y., ZAMbon, J. J., Genco, R. J. \& NeIders, M. E. (1985). Rapid identification of periodontal pathogens in subgingival plaque: comparison of indirect immunofluorescence microscopy with bacterial culture for the detection of Actinobacillus actinomycetemcomitans. Journal of Dental Research 64, 793-798.

Conner, B. J., Reyes, A. A., Morin, C., Itakura, L., TePlitz, R. L. \& Wallace, R. B. (1983). Detection of sickle cell $\beta^{\text {s- }}$ globulin allele by hybridization with synthetic oligonucleotides. Proceedings of the National Academy of Sciences of the United States of America 80, 178-282.

Cristersson, L. A., Slots, J., Zambon, J. J. \& Genco, R. J. (1985). Transmission and colonization of Actinobacillus actinomycetemcomitans in localized juvenile periodontitis. Journal of Periodontology 56, $127-131$.

Cristersson, L. A., Albini, B., Zambon, J. J. \& Genco, R. J. (1987a). Tissue localization of Actino- bacillus actinomycetemcomitans in human periodontitis. I. Light, immunofluorescence, and electron microscope studies. Journal of Periodontology 58, 529-539.

Cristersson, L. A., Wikesjö, U. M. E., Albini, B., Zambon, J. J. \& Genco, R. J. (1987b). Tissue localization of Actinobacillus actinomycetemcomitans in human periodontitis. II. Correlation between immunofluorescence and culture techniques. Journal of Periodontology 58, 540-545.

Duerden, B. I., Goodwin, L. \& O'Neill, T. C. A. (1987). Identification of Bacteroides species from adult periodontal disease. Journal of Medical Microbiology 24, 133-137.

EISENSTEIN, B. I. \& ENGLEBERG, N. C. (1986). Applied molecular genetics: new tools for microbiologists and clinicians. Journal of Infectious Diseases 153, 416-430.

FALKow, S. (1985). The use of DNA hybridization for the identification of pathogenic bacteria. In Rapid Methods and Automation in Microbiology and Immunology, pp. 30-33. Edited by K. O. Habermehl. Berlin: Springer.

FrEDERIKSEN, W. (1987). International Committee on 
Systematic Bacteriology: Subcommittee on Pasteurellaceae and related organisms. International Journal of Systematic Bacteriology 37, 474.

French, C. K., Savitt, E. D., Simon, S. L., Eklund, S. M., Chen, M. C., Klotz, L. C. \& Vaccaro, K. K. (1986). DNA probe detection of periodontal pathogens. Oral Microbiology and Immunology 1, 58-62.

GMÜr, R., HrodeK, K., SAXER, U. P. \& GUGgenheim, B. (1986). Double-blind analysis of the relation between adult periodontitis and systemic host response to suspected periodontal pathogens. Infection and Immunity 52, 768-776.

Göbel, U., Gaiser, A. \& Stanbridge, E. J. (1987a). Oligonucleotide probes complementary to variable regions of ribosomal RNA discriminate between Mycoplasma species. Journal of General Microbiology 133, 1969-1974.

Göbel, U., MaAs, R., HaUn, G., Vinga-Martins, C. \& STANBRIDGE, E. J. (1987b). Synthetic oligonucleotide probes complementary to ribosomal RNA for group- and species-specific detection of mycoplasmas. Israel Journal of Medical Sciences 23, 742-746.

GÖBEL, U., MAAS, R. \& ClAD, A. (1987c). Quantitative electroelution of oligonucleotides and large DNA fragments from gels, and purification by electrodialysis. Journal of Biochemical and Biophysical Methods 14, 245-260.

Gray, M. W., Sankoff, D. \& Cedergren, R. J. (1984). On the evolutionary descent of organisms and organelles: a global phylogeny based on a highly conserved core structure in small subunit ribosomal RNA. Nucleic Acids Research 12, 5837-5852.

Haapasalo, M., Ranta, H., Ranta, K. \& Shah, H. (1986). Black-pigmented Bacteroides spp. in human apical periodontitis. Infection and Immunity 53, 149153

HAUN, G. \& GöBEL, U. (1987). Oligonucleotide probes for genus-, species-, and subspecies- specific detection of representatives of the genus Proteus. FEMS Microbiology Letters 43, 187-193.

JoHNSON, J. L. \& HARICH, B. (1986). Ribosomal ribonucleic acid homology among species of the genus Bacteroides. International Journal of Systematic Bacteriology 36, 71-79.

Kuritza, A. P., Getty, C. E., Shaughnessy, P., Hesse, R. \& SALYERS, A. A. (1986). DNA probes for identification of clinically important Bacteroides species. Journal of Clinical Microbiology 23, 343349.

Lane, D. J., Pace, B., Olsen, G., Stahl, D. A., Sogin, M. L. \& PACE, N. R. (1985). Rapid determination of 16S ribosomal RNA sequences for phylogenetic analyses. Proceedings of the National Academy of Sciences of the United States of America 82, 69556959.

Lennette, E. H., Balows, A., Hausler, W. J., JR \& Shadomy, H. J. (1985), Manual of Clinical Microbiology, 7th edn. Washington, DC: ASM.

Miyoshi, T., Hanazawa, S., Hirose, K., Saitoh, K., Amano, S., Ohmori, Y. \& Kitano, S. (1986). Humoral antibody response against Bacteroides gingivalis-specific antigen recognized by monoclonal antibody in adult periodontal patients. Infection and Immunity 53, 366-371

MoORE, W. E. C. (1987). Microbiology of periodontal disease. Journal of Periodontal Research 22, 335-341.

Moore, W. E. C., Holdeman, L. V., Cato, E. P., GOOD, I. J., SMITH, E. P., RanNey, R. R. \&
Palcanis, K. G. (1984). Variation in periodontal floras. Infection and Immunity 46, 720-726.

Moore, W. E. C., Holdeman, L. V., Cato, E. P., Smibert, R. M., Burmeister, J. A., Palcanis, K. G. \& RANNEY, R. R. (1985). Comparative bacteriology of juvenile periodontitis. Infection and Immunity 48, 507-519.

Moore, L. V. H., Moore, W. E. C., Cato, E. P., Smibert, R. M., Burmeister, J. A., Best, A. M. \& RANNEY, R. R. (1987). Bacteriology of human gingivitis. Journal of Dental Research 66, 989-995.

Newman, M. G. \& Socransky, S. S. (1987). Predominant cultivable microbiota in periodontitis. Journal of Periodontal Research 12, 120-128.

Pace, N. R., Stahl, D. A., Lane, D. J. \& Olsen, G. J. (1986). The analysis of natural microbial populations by ribosomal RNA sequences. In Advances in Microbial Ecology, pp. 1-52. Edited by K. C. Marshall. New York: Plenum Press.

Potts, T. V., Zambon, J. J. \& Genco, R. J. (1985). Reassignment of Actinobacillus actinomycetemcomitans to the genus Haemophilus as Haemophilus actinomycetemcomitans comb. nov. International Journal of Systematic Bacteriology 35, 337-341.

Roberts, M. C., Moncla, B. \& KenNy, G. E. (1987). Chromosomal DNA probes for the identification of Bacteroides species. Journal of General Microbiology 133, 1423-1430.

Salyers, A. A., LynN, S. P. \& Gardner, J. F. (1983). Use of randomly cloned DNA fragments for identification of Bacteroides thetaiotaomicron. Journal of Bacteriology 154, 287-293.

Sanger, F., Nicklen, S. \& Coulson, A. R. (1977). DNA sequencing with chain terminating inhibitors. Proceedings of the National Academy of Sciences of the United States of America 74, 5463-5467.

SLoTs, J. (1979). Subgingival microflora and periodontal disease. Journal of Clinical Periodontology 6, 351382.

SLOTS, J. \& GeNCO, R. J. (1984). Black pigmented Bacteroides species, Capnocytophaga species, and Actinobacillus actinomycetemcomitans in human periodontal disease: virulence factors in colonization, survival, and tissue destruction. Journal of Dental Research 63, 412-421.

Slots, J., EMrich, L. J., Genco, R. J. \& Rosling, B. G. (1985). Relationship between some subgingival bacteria and periodontal pocket depth and gain or loss of periodontal attachment after treatment of adult periodontitis. Journal of Clinical Periodontology 12, 540-542.

Strzempko, M. N., Simon, S. L., French, C. K., LIPPKE, J. A., RaIA, F. F., SAVITT, E. D. \& Vaccaro, K. K. (1987). A cross-reactivity study of whole genomic DNA probes for Haemophilus actinomycetemcomitans, Bacteroides intermedius, and Bacteroides gingivalis. Journal of Dental Research 66, 15431546.

VISCIDI, R. P. \& Yolken, R. G. (1987). Molecular diagnosis of infectious diseases by nucleic acid hybridization. Molecular and Cellular Probes 1, 3-14.

Weisburg, W. G., Oyaizu, Y., Oyaizo, H. \& Woese, C. R. (1985). Natural relationship between Bacteroides and flavobacteria. Journal of Bacteriology 164, 230-236.

ZAMBON, J. J. (1985). Actinobacillus actinomycetemcomitans in human periodontal disease. Journal of Clinical Periodontology 12, 1-20. 